\title{
The Use of the Cementing Marker minkəbl in the Holy Qur'an: A Semantic Analysis
}

\author{
Duaa Hajjaj \\ Department of English \\ Tafila Technical University, Jordan \\ Aiman Eid Al-Rawajfeh \\ Tafila Technical University \\ Tafila 66110, Jordan, P.O. Box 179
}

\begin{abstract}
This paper presents a semantic analysis for the word minkəbl "before or previously" as a cementing marker in the Holy Qur'an. Eight verses, where the word minkəbl is used as a cementing marker, were selected for the purpose of analysis. The analysis of the data shows that the use of the cementing marker minkəbl serves to add one intended meaning to the verse.
\end{abstract}

Keywords: Qur'an, cementing markers, language, semantics, meaning, before.

\section{Introduction}

Semantics creates an interesting area for analyzing the meaning of linguistic items. It is the study of meaning (Lyon, 1977). The word meaning, in particular, is very important for the semantic analysis of sentences. It can help one determine the meaning of sentences as "the meaning of a sentence can be predicted from the meaning of the words it contains" (Aliyeva, 2016, p. 1763).

The Holy Qur'an - the sacred text of Islam (Mozaheb et al., 2017) presents a rich source for linguistic information in general and semantic analysis in particular. It uses a well-organized language that makes it a reliable source for language creativity. The language of the Holy Qur'an is "unique in its eloquence and style, which differentiate[s] it from any other Classical Arabic text" (Alrabiah et al., 2014, p. 2).

The language of the Holy Qur'an consists of words that have meaning. Moreover, the meaning of words in the Holy Qur'an is preserved (Allan, 2014). In other words, each word has its own meaning that can be found in any dictionary and in any Arabic text. For example, the word kulu "eat "in the following part of the verse has its original meaning "the act of swallowing food"- the meaning that can be found in the dictionary (ibid: 2014).

" الكلو من طيبات ما رزقناكم"

"Eat of the good food that we provided you with"

The meaning of words also develops and acquires new meaning (ibid). For example, the same word, (ta)kulu, can have another meaning in the following verse - the act of swallowing and ownership (ibid: 2014).

"و لا تاكلو ا امو الكم بالباطل"

"And do not take others' wealth unfairly"

Words in the Holy Qur'an can serve as cementing markers. Cementing markers are common words that are used in the middle between two sentences or phrases and give each sentence its own different meaning (Al-Rawajfeh and AlKhalafat, 2019). For example, the word sawaa 'whether' in the Holy Qur'an gives each sentence in the verse joined to it a different meaning. The following example explains the use of sawaa as a cementing marker (Al-Mrayat et al., 2019223 :):

1. inna allaðiina kafaro sawaa?on Palayhim Paجanðartahom am lam tonðirhom la yo?minoon. Al-Baqarah, verse 6

'Indeed, those who disbelieve - it is all the same for them whether you warn them or do not warn them - they will not believe'.

The word sawaa 'whether' in the example above is a cementing marker that connects two sentences with a different meaning for each one. In the first part, inna allaðiina kafaro sawaa?on, it gives the meaning that disbelievers are the same. In the second part, sawaa?on Palayhim ?a?anðartahom am lam tonðirhom la yo?minoon, it gives the meaning that whether disbelievers are worn or not, they won't believe - the sameness. (ibid: 2019) 
Researchers have analyzed the words of the Holy Qur'an for various purposes. For example, Allan (2014) discussed the role that the Holy Qur'an played in preserving the meaning of Arabic words and its development. On the other hand, Mozaheb et al., (2017) analyzed several verses in the Holy Qur'an to discuss several aspects of language. They pointed out that the linguistic heritage of the Qur'an is not restricted to one language and it is the sign of God.

Other researchers have focused on pragmatic aspects of the Holy Qur'an. For example, Ghazal (2017) analyzed a number of verses in the Holy Qur'an using Grice's maxims to highlight the intentional meaning of the verses. He concluded that floating these maxims reflects the style of language of the Holy Qur'an and develops one's ability to find the implied meaning.

This paper contributes to previous research on the language of the Holy Qur'an. Therefore, the present paper argues that the word minkabl "before or previously" is a cementing marker that gives a different meaning for each part of the verse and specifies one intended interpretation for it.

\section{Data Collection}

The data were collected from the Holy Qur'an. The sample consists of 8 verses containing the word minkabl. The word minkab in these verses functions as a cementing marker.

A purposive sample is used to collect the data. The researchers have selected the verses based on two criteria. First, the verse must contain the word minkabl. Second, the word must function as a cementing marker.

\section{Analysis and Discussion}

This section discusses the analysis of the eight verses that include the word minkabl, as a cementing marker. The following examples were taken from the Holy Qur'an:

In the verses below, the word before "من قبل" gives two meanings for each verse but asserts one for it. In particular, it is used as an adjective describing a noun in the first part of each verse. On the other hand, it serves as a cementing marker that indicates an order, a warning, and events to be accomplished before specific time when it is combined to the whole verse.

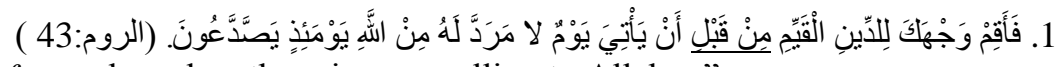

"So, direct your face toward the true religion before a day when there is no repelling to Allah...."

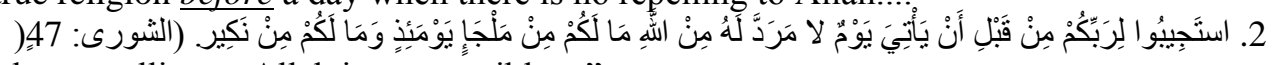

"Respond to Allah before a day when repelling to Allah is not possible...."

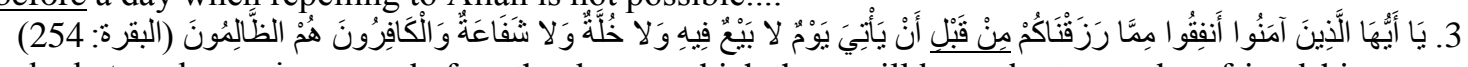

"Oh believers expend what we have given you before the day on which there will be no barter, and no friendship or intercession, and those who are disbelievers will be sinners."

In verse 1, the first part of the verse, "So, direct your face toward the true religion before," emphasizes an invitationscarifying oneself for the sake of true religion that one has already believed with before the present time. In other words, the word before is exploited to be used as an adjective describing a previous true religion that one believed with in the past. Combing the two parts of the verse using the cementing marker emphasizes an order to be accomplished at specific time. The addressee is ordered to sacrifice himself for the true religion and its instructions before the Judgment Day.

The word before in verse 2 is used as a cementing marker that emphasizes an order to be taken at specific time. The first part of the verse "Respond to Allah before" explains that the addresses are invited to respond to what the speaker has already asked for. Therefore, the word "before" shows an invitation that took place in the past. This invitation is described as a previous or past invitation. When reading the whole verse, one can notice that before is used to clarify an order to be taken at specific time. That is, the addressees have to obey their God before the Judgment Day.

The last verse above also includes the word before functioning as a cementing marker. The first part of verse 3 , "Oh believers expend what we have given you before" is an invitation for believers to spend their wealth that they had already owned for good deeds. The word before in this part of the verse describes the wealth that the addresses owned in the past. Thus, it is an old owned wealth. Hence, the second part of the verse, "...before the day on which there will be no barter, and no friendship or intercession, and those who are disbelievers will be sinners." indicates an order and limits the time during which this wealth must be spent. In other words, the addresses are ordered to spend their wealth on good deeds not at any time, but before specific time (the Judgment Day).

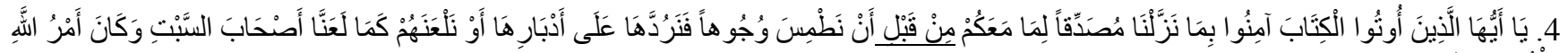

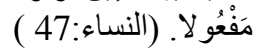


"Oh people who were given Al-ketab, believe what we have already revealed, asserting what you have, before we obliterate faces to turn them back or before we curse them as Ashab el-sabt ...."

In addition to orders that are to be committed before a specific time, the cementing marker before is also used to assert a warning. For instance, in verse 4, "Oh people who were given Al-ketab, believe what we have already revealed, asserting what you have before," one can understand that this part is an invitation for a group of people (ahlalketab) to believe what has already been revealed. In this part of the verse, the word before is used to show previous revealed knowledge. Combining it within the first and the second part of the verse, the word is a cementing marker that carries a specific meaning - a warning. The speaker warns the addresses in order to believe what has been revealed before an action (a punishment) that will be taken if they do not believe.

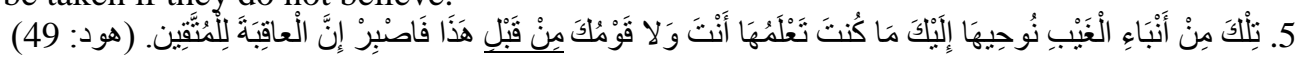

"That is from the unseen events that we reveal to you and those that are not known for you and for your tribe before this ..."

The cementing marker before can be also used to indicate situations revealed at specific time. The cementing marker in verse 5 explains situations that were not known for the addressee before specific time. In the first part of the verse, it indicates that the addressee is being notified about some of unseen situations that he and his tribe are not familiar with in the past. Therefore, the word "before" describes the unseen situations as previous unknown situations. Adding the cementing marker to the whole verse explains that these unseen events were not known to the addressee and his tribe before specific time - before the period when they had been declared ${ }^{1}$.

The cementing marker before is also used to specify a group of people. In verse 6 below, the first part 'For those who repented before' includes a speech to those who are repentant sinners in the past. The word before in this part indicates that the speech is directed for anyone who repented in the past. Combining the cementing marker before within the whole verse indicates that this speech is directed for a specific group of repentant sinners - those who repented before the guidance was able to convince them to repent.

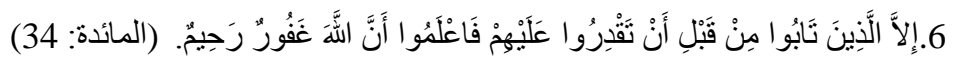

"For those who repented before you apprehend them, know that Allah is forgiving and merciful."

In the verses below, the word before "من قبل also serves as a cementing marker that asserts one meaning for the verse. In particular, the word is used to show a positive attitude. On the other hand, it serves as a cementing marker that indicates a negative meaning to the whole verse.

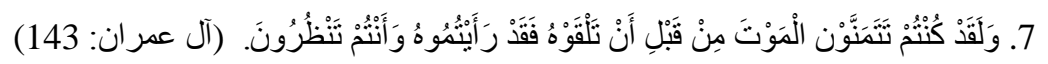

"You did wish death before you face it and you have seen it with your own eyes."

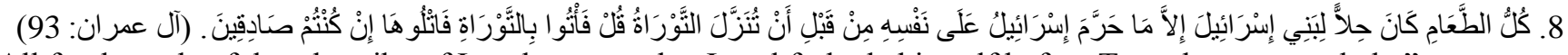
"All food was lawful to the tribe of Israel except what Israel forbade himself before Tawrah was revealed..."

For example, the interpretation of the first part of verse 7, "You did wish for death before" indicates the addressees" fulfilled wishing in the past. The addresses are rewarded by fulfilling their wishing that they had it before by the virtue of being martyrs and warriors ${ }^{2}$. The word before is used to show a fulfilled wishing in the past-a positive attitude. Combing the second part of the verse "...before you met it and now you have seen it with your own eyes", the sentence takes on the meaning that the addressees do not wish to die because they now can see that this wish would be very difficult to realize. In other words, the word before serves as a cementing marker that is exploited to show one's withdrawn from an action that was to be taken - a negative attitude.

Using the cementing marker in verse 8 also adds specific meaning to the interpretation. When reading the first part of the verse, "All food was lawful to the children of Israel except what Israel forbade himself before," one can understand that any type of food is permitted to be eaten by Israel's tribe except the one type that Israel forbade himself from in the past because of sickness. The word before is used in this part to indicate almost all types of food were permitted for the tribe - a positive meaning. On the contrary, when reading the first part of the verse with the second part, "...before Tawrah was revealed." a new interpretation is emphasized: Not all types of food are permitted for Israel's tribe because they have already been documented in Tawra, a reliable source ${ }^{3}$. In other words, the cementing marker is used to show a complete different meaning that contradicts the first revealed meaning.

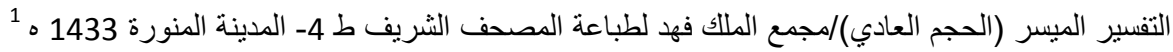

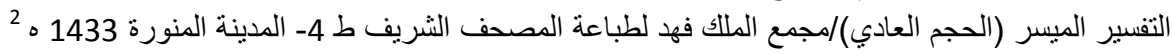

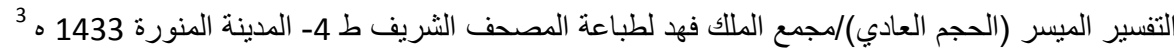


We have seen that the cementing marker minkabl is exploited to specify one particular intended meaning for the verses above. It explains an order, a warning, or events to be committed before specific time - the judgment Day and specification for a group of people. It also added a contradictory meaning within the two parts of the verse.

\section{Conclusion}

This paper presented a semantic analysis for the word minkəbl "before or previously" as cementing marker. It argued that the use of minkəbl gives a different meaning for each part of the verse and specifies one intended interpretation for the verse. It determined more clearly the intended meaning of the verse.

\section{References}

Aliyeva, K. (2016). About the different kinds of meanings of a sentence. Theory and Practice in Language Studies, 6(), $1762-1766$.

Al-Marayat, S. H.; Al-Rawajfeh, A. E.; Al-Zregat, A. M.; Al-Hanaktah, I. I. (2019). Cementing markers in the Holy Qura?an: The word sawaa? 'whether' as a model. International Journal of English and Education, 8(4), 220228.

Al-Rawajfeh, A. E.; Al-Khalafat, K. (2019). Cementing phrases in the Holy Qur'an. The second International Conference on Literature, Linguistics, and Translation. Tafila Technical University, Tafila, Jordan (April 2-4, 2019).

Alrabiah, M, Alhelewh, N, Al-Salman, A. Atwell E. (2014). An empirical study on

the Holy Qur'an based on a large classical Arabic corpus. International Journal of

Computational Linguistics, 5 (1). 1 - 13.

Ghazal, A. (2017). A Pragmatic Analysis of Some Qur'anic Verses: A Gricean Approach, International Journal of Linguistics. 9(1), 42-50.

Lyons, J. (1977). Semantics. Cambridge University Press: London

Shahiditabar, M. Mozaheb, M. Mohseni, M. Babaii , A. Dehchali, A. Mousavi, S. (2017). The place of language in the Holy Qur'an as a linguistic heritage. Journal of Applied Linguistics and Language Research, 4(4), 291-300.

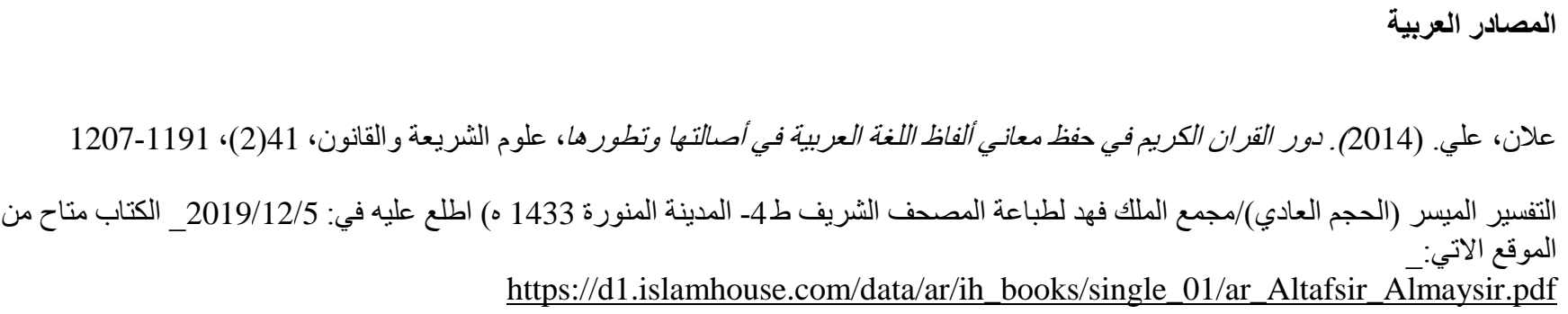

